\title{
The Anatomy of the Posterior Commissure
}

\section{Posterior Komissür'ün Anatomisi}

\section{Nuriye Guzin OZDEMIR}

İstanbul Training and Research Hospital, Neurosurgery Clinic, Istanbul, Turkey

Corresponding Author: Nuriye Guzin OZDEMIR / E-mail: guzozdemir@yahoo.com

\begin{abstract}
AIM: The connections of posterior commissure are defined. Its fibers mediate the consensual light reflex by interconnecting the pretectal nuclei. The fiber connections from the thalamic, pretectal, superior colliculus and the habenular nuclei are known, but they have not been shown anatomically. The present study is a fiber dissection study to define the anatomy of the posterior commissure.

MATERIAL and METHODS: Twenty formalin-fixed sheep heads were used in the study. The specimens were fixed in $10 \%$ formalin solution for 3 weeks. The arachnoidal and vascular structures were removed by using a surgical microscope magnification (x6-x40) and brains were again fixed for 4 weeks at $-20^{\circ} \mathrm{C}$. The fiber dissections were performed at Marmara University, Rhoton Laboratory. Also, a radiological tractographic study was carried on five healthy volunteers to see the posterior commissure cortical connections.

RESULTS: In fifteen sheep brains, the dimensions of the posterior commissure were measured as $1.36 \mathrm{~mm}$ (range $0.5-2.5 \mathrm{~mm}$ ) width, and as 4.6 $\mathrm{mm}$ (range 3-6 mm) length. In the dissection study, a frontotemporooccipital fascicle was observed to connect with the fibers of the posterior commissure. Diffusion tensor imaging scans showed the frontotemporooccipital tract to extend to posterior commissural region.

CONCLUSION: To our knowledge, this is the first anatomical and tractographic study regarding the posterior commissure. However, further human cadaveric studies are necessary.
\end{abstract}

KEYWORDS: Diffusion tensor imaging, Fiber dissection, Posterior commissure

öz

AMAÇ: Posterior komissür'ün lifleri, pretektal nükleusları bağlayarak konsensual ışık refleksine aracı olur. Talamik, pretektal, tektal, superior kolikulus lifleri ve habenular çekirdeklerin liflerinin posterior komissür'de çaprazlaştı̆̆ı bilinmektedir. Ancak anatomik olarak gösterilmemiştir. Posterior komissür anatomisini tanımlamak için yapılan lif diseksiyon çalışması sunulmuştur.

YÖNTEM ve GEREÇLER: Yirmi koyun beyninde Marmara Üniversitesi Rhoton Laboratuvarı'nda diseksiyon yapıldı. Spesimenler \%10 formalin solüsyonunda 3 hafta bekletildi. Cerrahi mikroskop (x6-x40) altında araknoid-vasküler yapılar çıkartılarak beyinler $-20^{\circ} \mathrm{C}^{\prime}$ de bekletildi. Beş beyin, posterior fiksasyon-diseksiyon yetersiz olduğu için çalışmadan çıkartıldı. Beş beyinde anterior, lateral, posterior ve medial diseksiyon yapılarak her aşamada fotoğraflandı. On beyinde posterior komissür ortaya konacak şekilde hipokampal komissür düzeyinden diseksiyon yapıldı. Radyolojik çalışmada 5 gönüllü hastaya, difüzyon tensor görüntüleme yapılarak posterior komissür'ün lif bağlantısı incelendi.

BULGULAR: On beş koyun beyninde posterior komissür'ün ortalama kalınlığı 1,36 mm (0,5-2,5 mm), uzunluğu 4,6 mm (3-6 mm) olarak bulundu. Posterior komissür'ün her iki tarafta superior ve inferior kolikulusları bağladığı; habenula, pretektal, tektal ve periakuaduktal bölgeden kısa liflerle bağlantı kurduğu görüldü. Bazı spesimenlerde hipokampal komissür liflerinin splenial bölgede bu liflere eşlik ettiği izlendi. Talamik diseksiyondan sonra gözlenen frontotemporooksipital fasikülün posterior komissür'e uzandığı saptandı.

SONUÇ: Çalışmada diseksiyonla posterior komissür'ün frontotemporooksipitopontin bağlantısı gösterilmiştir. Araştırma posterior komissür'ün lif bağlantılarını ortaya koyacak insan kadavra çalışmalarıyla desteklenmelidir.

ANAHTAR SÖZCÜKLER: Difüzyon tensor görüntüleme, Lif diseksiyonu, Posterior komissür

\section{INTRODUCTION}

Cerebral white matter is composed of myelinated fibers classified into three types of fasciculi; association, commissural and projection fibers. Association fibers interconnect different cortical regions of the same hemisphere, commissural fibers interconnect the two hemispheres across the median plane, and projection fibers connect the cortex with caudal parts of the brain and the spinal cord $(2,7)$.

Commissural fibers are corpus callosum, anterior commissure, hippocampal commissure and the posterior commissure. The posterior commissure is located in the inferior pineal lamina and it is one of the commissural fibers of the brain known to be important in the pupillary light reflex. Its fibers acquire their medullary sheath early. Various nuclei are associated with the posterior commissure. The best known of them is the interstitial nucleus of the posterior commissure, nucleus of Darkschewitsch; another one is the interstitial nucleus of Cajal. The first one is located in the central grey substance of the upper end of the cerebral aqueduct, in front of the nucleus of the oculomotor nerve. The second one is near the upper end of the oculomotor fasciculus $(5,6,14,22)$. The posterior commissure is detected and defined early in the human embryo but the connections of this structure except for the nucleus of Darkschewitsch are unknown. Its fibers interconnect the pretectal nuclei and mediate the consensual 
pupillary light reflex. Some fibers are believed to be derived from the posterior part of the thalamus and from the superior colliculus and to continue directly to the medial longitudinal fasciculus. Fibers from the thalamic, pretectal, tectal region, fibers from the superior colliculus and the habenular nuclei are known to connect with the posterior commissure, but they have not been shown anatomically $(3-5,12)$.

Although recent reports about other commissural fibers of the brain, such as corpus callosum, anterior commissure and hippocampal commissure are present in the literature, the anatomy and connections of the posterior commissure have not been studied except for an early report $(2,5,10,21)$. The aim of this study was to evaluate the connections of the posterior commissure and especially to show the cortical fiber relationship anatomically and tractographically.

\section{MATERIAL and METHODS}

Twenty formalin-fixed sheep heads were used in the study. The dissection was performed using the operating microscope at the Rhoton Anatomy Laboratory of Marmara University, Faculty of Medicine. Craniectomy to evacuate the brains for the first 5 heads and craniotomy for the latter 15 heads was performed with the help of a craniotome. The specimens were fixed in $10 \%$ formalin solution for 3 weeks. The arachnoidal and vascular structures were removed by using the magnification of the surgical microscope (x6-x40) and brains were again fixed for 4 weeks at $-20^{\circ} \mathrm{C}$, after which the dissection began. Five specimens were excluded from the study since the fixations was not sufficient to dissect the posterior structures. Gross anatomical dissection was done to define the posterior structures of the brain. In 5 brains, the dissections were done as dorsal, ventral, lateral, and medially using Klingler's method. Digital photographs were taken at each step (Figures 1A-D). Dissection was made on all sides to understand the anatomic relationship of the posterior commissure and then, only posteriorly to see the posterior commissure anatomy (Figures 2A-D). In ten specimens, the posterior commissure together with the tectum and tegmentum were dissected, removing the upper part of the telencephalon.

As a radiological study, five healthy subjects with no history of neurologic pathology were recruited for the study. All patients provided written consent for the study, which was approved by the institutional review board at the Marmara Neurological Sciences Institute. Five volunteer patients underwent tractographic investigation to understand the upper and lower fiber tract pathway of the posterior commissure. A radiological tractographic study was carried on five healthy volunteers to see the posterior commissure cortical connections. Brain magnetic resonance imaging (MRI) was performed using a whole-body scanner (1.5- T, Siemens Magnetom, Espree, Germany) with an eight-channel head coil. Diffusion tensor imaging (DTI) tractography was performed using a single-shot multislice spin echo-echo planar sequence. Slice thickness was 3 to $5 \mathrm{~mm}$.

\section{RESULTS}

In 15 sheep brains, the dimensions of the posterior commissure were measured as $1.36 \mathrm{~mm}$ (range 0.5-2.5 mm) width and $4.6 \mathrm{~mm}$ (range 3-6 $\mathrm{mm}$ ) length.

The posterior commissure was observed to join both superior and inferior colliculi on both sides (Figures 3A, B; 4). Short fibers coming from the habenula, pretectal, and tectal regions
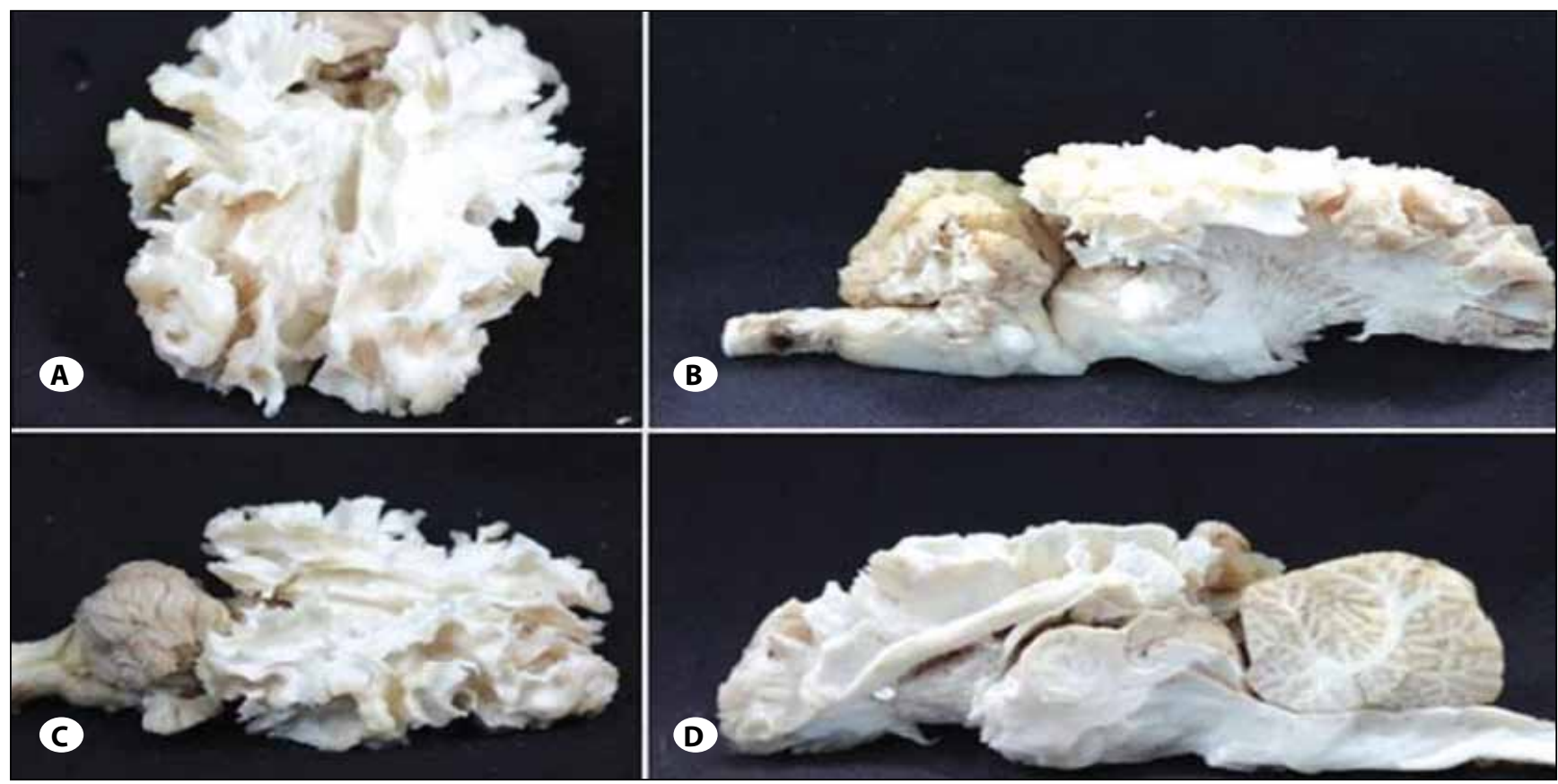

Figure 1: A-D) Gross anatomical dissection: Dorsal, ventral, lateral and medial dissection views respectively. 
and from periaqueductal grey matter nuclei were identified. Some hippocampal commissural fibers were seen to join these fibers at the splenial region but this was not shown in all the specimens (Figures 2A-D). After removal of the upper part of the telencephalon and posterior dissection, a frontotemporoparietooccipital fascicle was observed. This tract was followed to the tectal region and seen to end in the superior collicular region. This tract was observed in all the specimens. However, a tract towards the cerebellar region could not be dissected (Figures 5A, B).

DTI scans showed the frontotemporooccipital tract to extend to the posterior commissural region (Figures 7A, B). As in anatomical dissection, an inferior tract towards the cerebellum could not be observed (Figures 6A, B).

\section{DISCUSSION}

The commissures of the telencephalon are the anterior com- missure, the hippocampal commissure, corpus callosum and posterior commissure. Anterior and hippocampal commissures are present in all vertebrates, whereas corpus callosum is phylogenetically new and found in placental mammals only. Corpus callosum is the most prominent commissure, connecting most of the frontoparietal fibers of both hemispheres, limited anteriorly by the anterior commissure and posteriorly by the hippocampal commissure (12).

In humans, the anterior commissure carries olfactory and neocortical fibers from the temporooccipital region, and the hippocampal commissure carries fibers from the hippocampal formations together with neocortical fibers (the splenium) from the posteromedial aspect of the hemispheres (12).

The posterior commissure is not well defined in the literature. The subcommissural organ, a specialized neuroepithelium located at the dorsal midline underneath the posterior
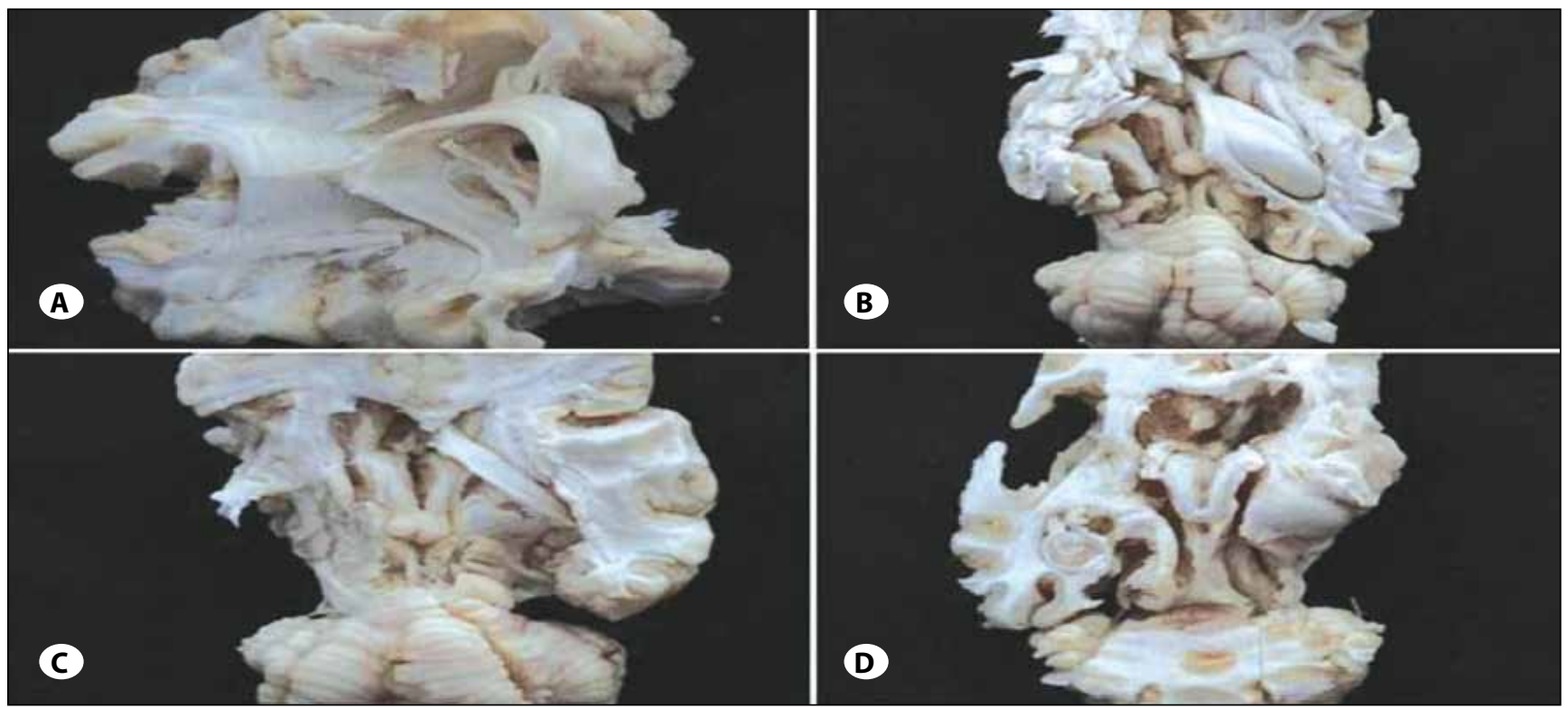

Figure 2: A-D) Dissection showing the hippocampal commissural fibers and removal of it to see the frontotemporoparietal connections of the posterior commissure.
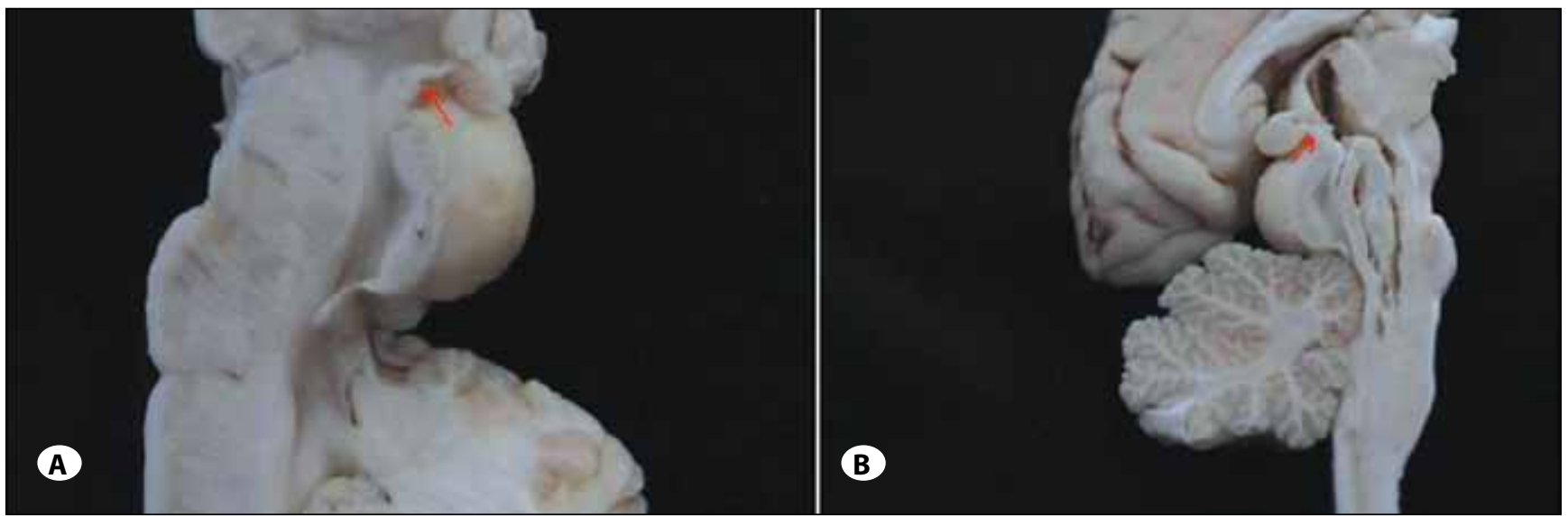

Figure 3: A, B) Sagittal sections of the sheep brain showing the posterior commissure under the pineal gland (red arrows). 


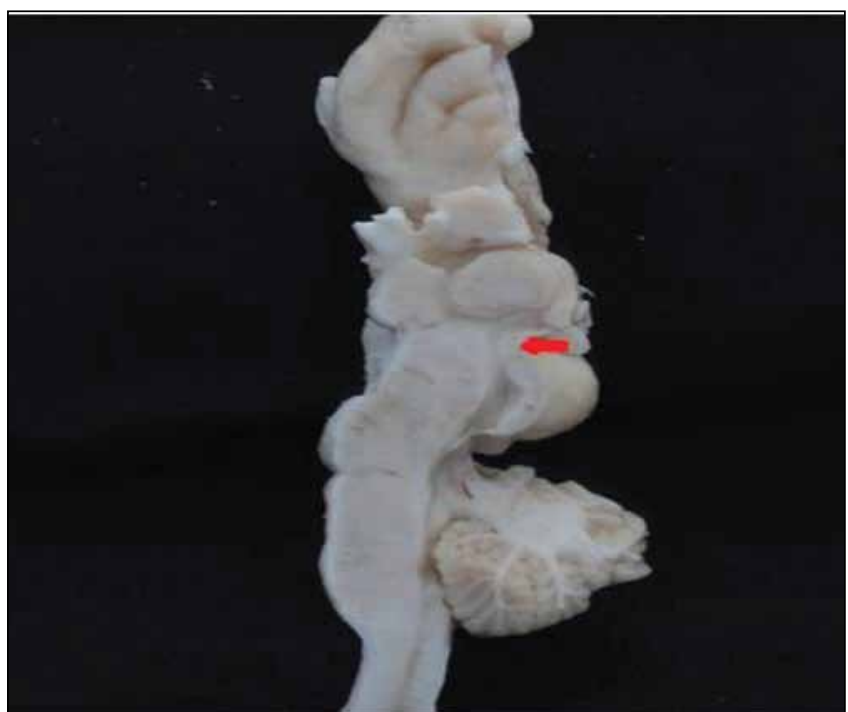

Figure 4: Sagittal section showing the posterior commissure (red arrow). commissure, releases the subcommissural organ spondin, a large glycoprotein belonging to the thrombospondin superfamily that shares molecular domains with axonal path-finding molecules. The subcommissural organ is thought to be involved in the development of the posterior commissure $(3,12)$. In our anatomical study, we observed the posterior commissure but we could not distinctly identify the subcommissural organ.

The posterior commissure is located in the posterior third ventricle, composed of the roof, floor, posterior wall and both lateral walls. The posterior wall within the third ventricle extends from the suprapineal recess above to the cerebral aqueduct below and consists of the suprapineal recess, the habenular commissure, the pineal body and its recess, the posterior commissure and the cerebral aqueduct. The only structure in the posterior wall in the quadrigeminal cistern is a pineal body and is concealed by the splenium above, thalamus laterally and the quadrigeminal plate and the vermis below (20). In this study, the posterior commissure was
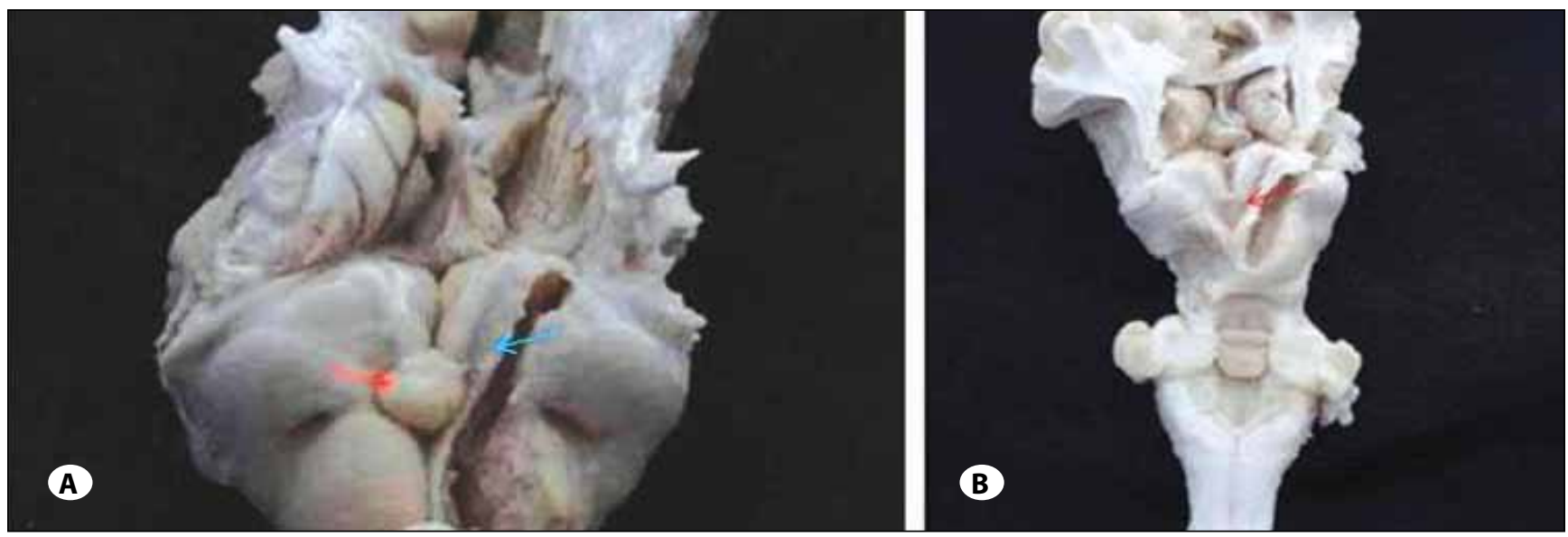

Figure 5: A) Pineal gland is seen in close-up view with the fiber tract extending to the frontotemporal region on the left side (red and blue arrows respectively). B) Pineal gland and after removal of the pineal gland, the posterior commissure (red arrow) and the fiber tract is seen after a horizontal dissection.
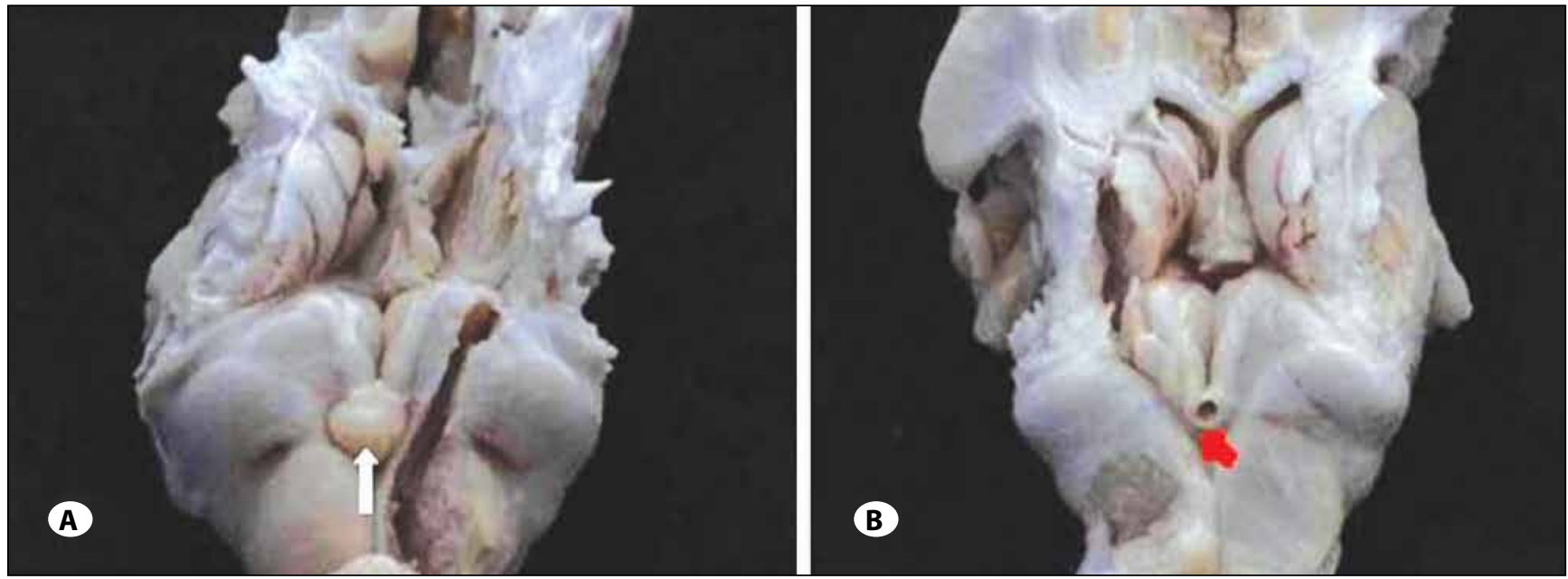

Figure 6: A, B) Pineal gland and after removal of the pineal gland; the frontotemporooccipitopontine tract connecting with the posterior commissure and superior colliculus in close-up views (white and red arrow respectively). 

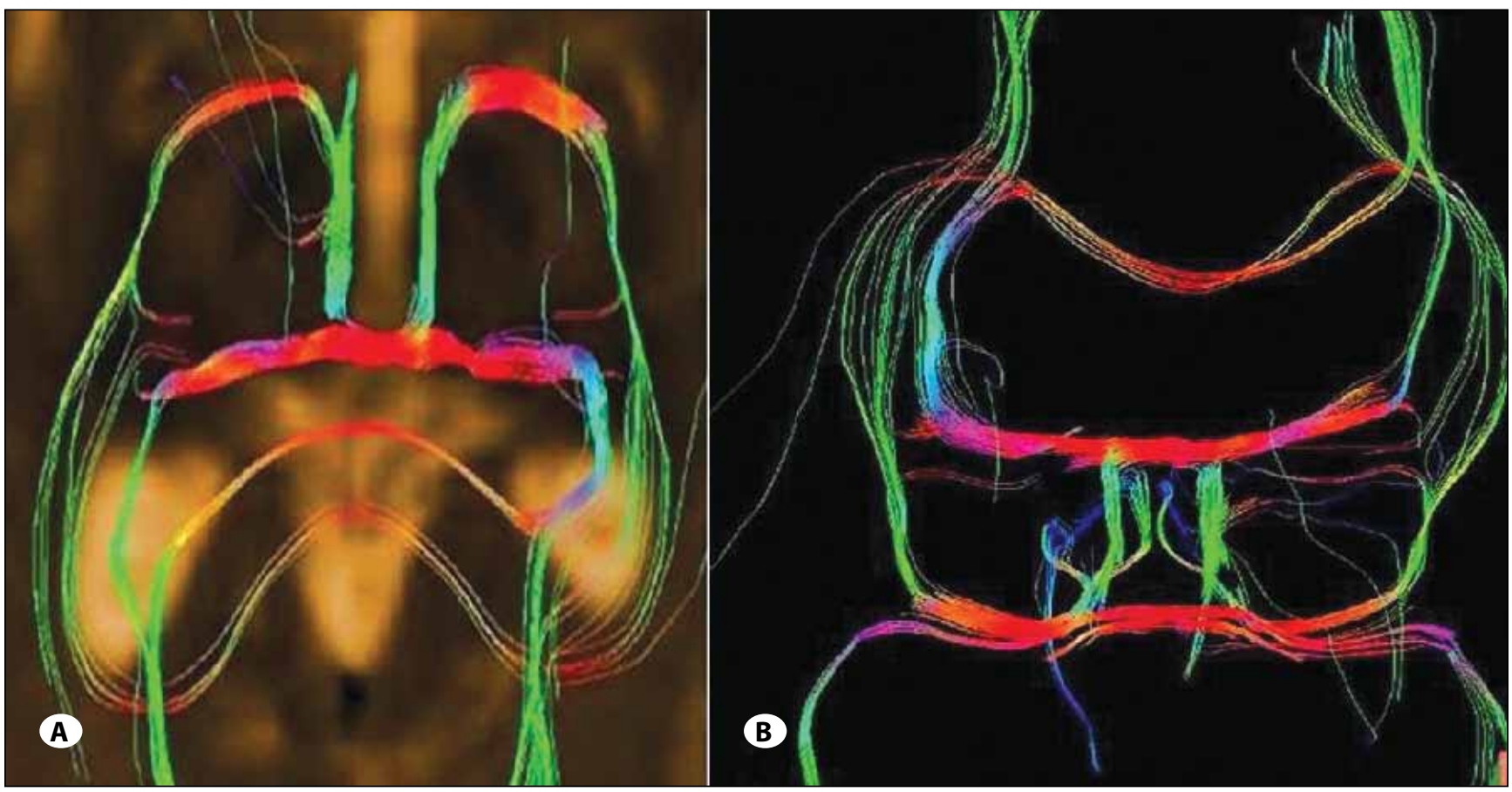

Figure 7: A, B) DTI showing the frontotemporal fiber connections of the posterior commissure.

found to be located in the posterior wall of the third ventricle by dissecting 15 brains of sheep and there was no variation.

The posterior commissure connects the fibers of the pretectal area. There are myelinated and non-myelinated fibers connecting the pineal gland and the pretectal area. Recently, a new paired tract has been found distinct from the posterior commissure. These tracts form a structural component of the wall of the pineal recess. These fibers are myelinated, invade the pineal gland, and can be traced a short distance into the lateral pre-tectal area (15). Also, a quantitative analysis of the myelinated axons of commissural fibers in the rat brain demonstrated a heterogeneous distribution of myelinated axons in the posterior and habenular commissures (13).

Functionally, the posterior commissure serves as a pathway for impulses related to eye-movements, and there is a close association between the posterior commissure and the medial longitudinal bundle. However, a relationship was observed between the development of the cerebellum and the posterior commissure that suggests that the more important functions of the commissure might be associated with posture and the integration of body movement rather than with movement of the eyes and visual influences $(5,15$, 17).

Experimental studies are present showing the association of the periaqueductal neurons with the posterior commissure and functional and anatomical fiber analysis of the posterior commissure has been performed to study the pupillary reflex (6).

A study showing the posterior commissural connections of area pretectalis and neighboring structures with special reference to the pupilloconstrictory pathway via the posterior commissure was also reported (14). All these studies were related to the light reflex function of the posterior commissure which was already known. We also observed the posterior commissure to connect the right and left pretectal regions in accordance with the literature reports and classical anatomical knowledge.

Besides being a connective area between the tectal areas, the posterior commissure may have a relationship with the optic pathways. We know that visual pathways originate from the temporal half of the ipsilateral retina as nerve fibers of the optic tract. The optic tract begins at the posterolateral corner of the optic chiasma and passes posterolaterally between the anterior perforated substance and tuber cinereum. Their fibers lie superior to medial aspect of the crus cerebri. The optic tract enters the lateral geniculate body and divides into two roots, the medial of which passes to the medial geniculate body. The optic radiation starts at the lateral geniculate body. The minority of optic tract fibers bypass the lateral geniculate nucleus entirely, traveling to the midbrain. These fibers mediate the pupillary light reflex in the pretectal area as described. The posterior commissure connects the left and right pretectal area and contains fibers from cell bodies in the pretectal and neighboring regions, including the dendrite of Müller cell M1. However, the studies showed that interaction between neurons in the left and right pretectal regions is not crucial for the responses $(11,19)$.

Two patterns of visual pathways were found. The optic radiation ran more commonly deep in the whole superior and middle temporal gyri and superior temporal sulcus. The op- 
tic radiation was closely surrounded in all cases by an inferior longitudinal fascicle (ILF) and a parietooccipitotemporopontine fascicle. The anatomy of the inferior longitudinal fasciculus and its function are not totally understood. It connects the occipital lobe with the anterior temporal lobe and is reported to subserve the language semantics in parallel with the inferior occipital fasciculus. It joins the posterior occipitotemporal regions to the temporal pole and is relayed by the uncinate fasciculus connecting the anterior temporal pole to the frontobasal areas $(11,16,19)$.

The inferior longitudinal bundle was originally thought to consist of long tracts connecting the visual areas of the occipital lobe with the anterior lobe, possibly playing a role in visual memory. We also observed in our study that the frontotemporooccipitopontine fibers connect with the posterior commissure. However, the anatomical differences between sheep and human brain stop us from declaring that this is the parietooccipitotemporopontine fascicle accompanying the inferior longitudinal fascicle together which surround the optic tract, since animal studies have shown that animals do not have an inferior longitudinal fascicle. The fascicle we identified may be the tract playing a role in visual formation, and this information from the opposite hemisphere is thought to be carried by the posterior commissure $(8,9,11,16)$.

The occipitopontine projection originates in cortical areas that respond to visual stimulation. The occipitopontine tract is reported to be associated with eye pursuit movements and may also be associated with visual perception (16). Each occipital hemisphere receives information from the opposite half of the visual world. The visual information is transferred to a visual word form system located in the inferior occipitotemporal white matter. Information from the left side of the visual field is received by the right visual cortex and is transferred to the word form system in the left hemisphere. This transfer occurs through the posterior commissure and splenium of the corpus callosum and is disrupted in alexia without agraphia (9). We could not show the inferior longitudinal projection system, since it is absent in animals. In this anatomical study, a distinct fascicle was shown anatomically from the frontotemporooccipitopontine region to the superior and inferior collicular area (tectal region) and crossing at the posterior commissure in all the specimens after removal of the upper part of the telencephalon and posterior dissection.

Another function of the posterior commissure is related to the vestibular pathway. Vestibular tracts as vestibular mesencephalic, and the lateral vestibular tegmental cross in the posterior commissure before connecting with the nucleus of the posterior commissure, and the interstitial nucleus. The efferent connection is the commissuro-medullaris, and the interstitio-spinalis tracts in a downward direction towards the medial part of the medial longitudinal bundle, forming the most cephalic portion of the medial longitudinal bundle. This anatomy may explain how the posterior commissure may have a cerebellar role, rather than a functional role in the light reflex in some animals. It has been suggested that there are fibers passing from the commissural nuclei to the ipsilateral globus pallidus, and also to the rubral area $(5,14)$. Knowing that there is a pathway between the cerebellum and the rubral area via the cerebellar peduncles, the commissural fibers might have a connection to the cerebellar area. We could not show the fiber relationship between the posterior commissural fibers and the cerebellum, and the vestibular tracts crossing at the posterior commissure. In sheep, the cerebellum has a major role in balance and coordination and it is reasonable not to be able to demonstrate the vestibular fibers crossing at the posterior commissure. This is also true for the human brain.

The importance of anterior and posterior commissure and individual variations and tractographic anatomical study of the insular region have been reported in the literature $(1,18)$, but there is no tractographic study related to the posterior commissure. We used DTI for identification of the fibers of the posterior commissure in the human brain, but the patient number was limited and a distinct tract could not be shown in all the patients.

In this anatomical and radiological study, we showed the tract connection of the posterior commissure with the thalomocortex anatomically and tractographically with DTI as a preliminary work, but we could not demonstrate the inferior relationship.

\section{CONCLUSION}

The posterior commissure connects the superior colliculi which is involved in the bilateral pupillary light reflex. We observed a frontotemporooccipitopontine tract that may play a role visual information. To our knowledge, this is the first anatomical study showing the fibers with the fiber dissection technique using the Klingler's method and tractographic study regarding the posterior commissure. However, there are limitations of this study, as the study was done on sheep brains and there are anatomical differences. Further human cadaveric and anatomical studies, and also further tractographic studies with a larger patient group, are necessary to understand the fiber connections of the posterior commissure.

\section{ACKNOWLEDGEMENT}

I wish to include special thanks to the radiology technician Serdar Erbil at the Marmara University Radiology Department for giving his time and effort for the tractography of the volunteer patients. 


\section{REFERENCES}

1. Davies KG, Daniluk S: Importance of individual variation of anterior commissure-posterior commissure-derived subthalamic nucleus coordinates in deep brain stimulation targeting. Stereotact Funct Neurosurg 86(4):266-267, 2008

2. Fernández-Miranda JC, Rhoton AL Jr, Alvarez-Linera J, Kakizawa $Y$, Choi C, de Oliveira EP: Three-dimensional microsurgical and tractographic anatomy of the white matter of the human brain. Neurosurgery 62(6 Suppl 3):989-1026, 2008

3. Grondona JM, Hoyo-Becerra C, Visser R, Fernández-Llebrez P, López-Ávalos MD: The subcommissural organ and the development of the posterior commissure. Int Rev Cell Mol Biol 296: 63-137, 2012

4. Hoyo-Becerra C, López-Avalos MD, Cifuentes M, Visser R, Fernández-Llebrez $\mathrm{P}$, Grondona JM: The subcommissural organ and the development of the posterior commissure in chick embryos. Cell Tissue Res 339(2):383-395, 2010

5. Keene MF: The connexions of the posterior commissure: A study of its development and myelination in the human foetus and young infant, of its phylogenetic development, and of degenerative changes resulting from certain experimental lesions. J Anat 72(Pt 4):488-501, 1938

6. Lara MH: Periaqueductal neurons associated to the posterior commissure: A morphological study in the hedgehog, rat and cat. Anat Anz 159(1-5):195-201, 1985

7. Maheshwari M, Klein A, Ulmer JL: White matter: Functional anatomy of key tracts. In: Faro SH, Feroze BM, Law M (eds). Functional Neuroradiology: Principles and Clinical Applications. NewYork: Springer, 2012:767-783

8. Mandonnet E, Nouet A, Gatignol P, Capelle L, Duffau H: Does the left inferior longitudinal fasciculus play a role in language? A brain stimulation study. Brain 130(Pt 3):623-629, 2007

9. Mulroy E, Murphy S, Lynch T: Alexia without agraphia. Ir Med J 104(4):124, 2011

10. Peltier J, Verclytte S, Delmaire C, Pruvo JP, Havet E, Gars DL: Microsurgical anatomy of the anterior commissure: Correlations with diffusion tensor imaging fiber tracking and clinical relevance. Operative Neurosurgery 69: 241-247, 2011

11. Peuskens D, van Loon J, Van Calenbergh F, van den Bergh $R$, Goffin J, Plets C: Anatomy of the anterior temporal lobe and the frontotemporal region demonstrated by fiber dissection. Neurosurgery 55(5):1174-1184, 2004
12. Raybaud C: The corpus callosum, the other great forebrain commissures, and the septum pellucidum: Anatomy, development, and malformation. Neuroradiology 52(6):447477, 2010

13. Sargon MF, Mas N, Senan S, Ozdemir B, Celik HH, Cumhur M: Quantitative analysis of myelinated axons of commissural fibers in the rat brain. Anat Histol Embryol 32(3):141-144, 2003

14. Shoumura K, Imai H, Kimura S, Suzuki T, Ara M: Posterior commissural connections of area pretectalis and neighboring structures in cat, with special reference to pupilloconstrictory pathway via posterior commissure. Jpn J Ophthalmol 31(2):289-304, 1987

15. Sparks DL: Anatomy of a new paired tract of the pineal gland in humans. Neurosci Lett 248(3):179-182, 1998

16. Uchida $Y$, Kimura E, Hirano T, Nishi S, Maeda Y, Yamashita $S$, Ueno-Shuto K, Tokutomi N, Kitajima M, Hirai T, Uchino M: Identification of the occipito-pontine tract using diffusiontensor fiber tracking in adult-onset adrenoleukodystrophy with topographic disorientation. Case Rep Neurol 3(2):113117,2011

17. Ullén F, Deliagina TG, Orlovsky GN, Grillner S: Visual pathways for postural control and negative phototaxis in lamprey. $J$ Neurophysiol 78(2):960-976, 1997

18. Wang F, Sun T, Li X, Xia H, Li Z: Microsurgical and tractographic anatomical study of insular and transsylvian transinsular approach. Neurol Sci 32(5):865-874, 2011

19. Wu W, Rigolo L, O'Donnell LJ, Norton I, Shriver S, Golby AJ: Visual pathway study using in vivo diffusion tensor imaging tractography to complement classic anatomy. Neurosurgery 70(1 Suppl Operative):145-156, 2012

20. Yamamoto I: Pineal region tumor: Surgical anatomy and approach. J Neurooncol 54(3):263-275, 2001

21. Yeo SS, Seo JP, Kwon YH, Jang SH: Precommissural fornix in the human brain: A diffusion tensor tractography study. Yonsei Med J 54(2):315-320, 2013

22. Yun S, Shoumura $K$, Ichinohe N, Hirama H, Amayasu $H$ : Functional and anatomical fiber analysis of the posterior commissure (PC) in the cat: Evidence for PC fibers of which stimulation elicits non-oculosympathetic pupillary dilation. J Hirnforsch 36(1):29-50, 1995 